\title{
Anna Szelągowska Wyzwania współczesnej polskiej polityki mieszkaniowej
}

\section{Challenges of contemporary Polish housing policy}

The article presents the author's insights into the Polish housing policy in the context of the country's current housing needs and challenges. Special attention is given to the role of housing policy and citizens' right to adequate and affordable housing, which are the main determinants of the national housing policy development. The author first defines the housing policy, the principles of its effectiveness, and describes its instruments. Next, she overviews the beginning and the achievements to date of Polish housing strategies and programmes, comparing them with the newest National Housing Programme (NHP). In the final section, the author assesses current housing needs in Poland and identifies how the NHP responds to the challenges of contemporary housing policy. The article draws on national and international statistics and the relevant literature on the subject.

\begin{tabular}{r|l}
\hline DOI & https://doi.org/10.31268/StudiaBAS.2021.15 \\
\hline Słowa kluczowe & $\begin{array}{l}\text { polityka mieszkaniowa w Polsce, potrzeby mieszkaniowe w Polsce, } \\
\text { Narodowy Program Mieszkaniowy }\end{array}$ \\
\hline Keywords & $\begin{array}{l}\text { housing policy in Poland, housing needs in Poland, National Housing } \\
\text { Programme }\end{array}$ \\
\hline 0 autorce & $\begin{array}{l}\text { profesor SGH, Katedra Miasta Innowacyjnego, Kolegium Nauk } \\
\text { O Przedsiębiorstwie, Szkoła Główna Handlowa w Warszawie • } \\
凶 \text { aszelag@sgh.waw.pl • ORCID 0000-0003-2670-6100 }\end{array}$ \\
\hline
\end{tabular}

\section{Wstęp}

Problematyka potrzeb mieszkaniowych jest z jednej strony tematem ważnym i bardzo potrzebnym w teorii i praktyce, z drugiej zaś należy do zagadnień niewdzięcznych do analizy. Wynika to m.in. z faktu, że pod względem sytuacji mieszkaniowej obywateli Polska plasuje się w niechlubnej czołówce państw członkowskich Unii Europejskiej, a czas oczekiwania na mieszkanie socjalne lub komunalne wynosi nawet 12-17 lat. Zmniejszanie dysproporcji w zakresie zaspokajania potrzeb mieszkaniowych jest wyzwaniem dla współczesnej polityki mieszkaniowej, która powinna się opierać na długoterminowych strategiach uwzględniających warianty pesymistyczne i optymistyczne. W żadnym z istniejących programów mieszkaniowych nie wskazuje się działań naprawczych w sytuacji, gdy założenia polityki mieszkaniowej nie zostaną zrealizowane w określonym czasie. Nie stosuje się stress testów, które umożliwiałyby weryfikację strategii dotyczącej polityki mieszkaniowej w trakcie jej trwania. Polityka mieszkaniowa powinna być prowadzona ponad podziałami, z myślą o wykluczonych mieszkaniowo obywatelach oraz o tych grupach społecznych, których nie stać na zakup mieszkania lub budowę domu albo nawet na opłacenie czynszu rynkowego za wynajem nieruchomości.

W artykule zastanowiono się nad następującym problemem badawczym: czy Narodowy Program Mieszkaniowy (NPM) odpowiada na wyzwania współczesnej polityki mieszkaniowej, a jeśli 
tak, to w jaki sposób. Celem niniejszego opracowania jest charakterystyka najnowszych form rządowego wsparcia gospodarstw domowych w zaspokajaniu ich potrzeb mieszkaniowych. Poddano weryfikacji hipotezę, zgodnie z którą pomimo szerokiego instrumentarium polityki mieszkaniowej realizacja głównego celu NPM do 2030 r. nie jest możliwa. Dokonano także oceny współczesnych potrzeb mieszkaniowych, zaproponowano dwa nowe wskaźniki oceny stopnia zaspokojenia społecznych potrzeb mieszkaniowych w Polsce oraz wskazano wyzwania, jakie niesie za sobą Narodowy Program Mieszkaniowy. Zastosowane w artykule metody badawcze obejmują analizę, syntezę logiczną i krytykęźródłową. Opracowanie powstało na podstawie krajowych i międzynarodowych danych statystycznych oraz wyselekcjonowanych pozycji literatury przedmiotu.

\section{Potrzeby mieszkaniowe i prawo do mieszkania jako przesłanka rozwoju polityki mieszkaniowej państwa}

Polityka mieszkaniowa stanowi zbiór uporządkowanych działań i zasad służących za wytyczne do podejmowania na szczeblu lokalnym, regionalnym i krajowym skoordynowanych decyzji administracyjnych co do sfery mieszkaniowej. Według J. Tinbergena polityka mieszkaniowa polega na wdrażaniu zmian w systemie mieszkaniowym modyfikujących istniejące instrumenty i zasady przyznawania świadczeń dla niezamożnych gospodarstw domowych o niezaspokojonych potrzebach mieszkaniowych ${ }^{1}$. Polityka mieszkaniowa, koncentrująca się na potrzebach mieszkaniowych społeczeństwa (zwanych „społecznymi potrzebami mieszkaniowymi”), jest częścią polityki społecznej. Zakres polityki społecznej został dobrze ujęty w definicji autorstwa J. Szczepańskiego, którego zdaniem „powstała ona jako metoda i teoria przezwyciężania niedostatku, jako szukanie sprawiedliwości w społeczeństwie i zapewnienie warunków życia we względnym dobrobycie wszystkim obywatelom państwa bez względu na ich pozycję w społeczeństwie, poziom wykształcenia i wykonywany zawód. Była więc przede wszystkim działaniem na rzecz klas ekonomicznie słabszych; była dążeniem do stworzenia możliwości zaspokajania potrzeb, bez kwalifikowania tych potrzeb"2. Ponieważ kwestia mieszkaniowa jest odwiecznym problemem społecznym wiążącym się z nierównościami społecznymi, istnieje silny związek między polityką mieszkaniową a polityką społeczną, którą L. von Bortkiewicz definiuje jako „wyrażone w ustawodawstwie i administracji stanowisko państwa wobec sprzeczności (antagonizmów) społecznych"”3. Wykorzystany w tej definicji przymiotnik "społeczny” stanowi wspólny mianownik zarówno dla polityki mieszkaniowej (zwanej także „społeczną polityką mieszkaniową”), jak i polityki społecznej.

Gdy uwzględnimy fakt, że potrzeby mieszkaniowe są potrzebami społecznymi ${ }^{4}$, o przynależności polityki mieszkaniowej do obszaru polityki społecznej świadczy także wspomniana już wcześ-

\footnotetext{
J. Tinbergen, Economic Policy. Principles and Design, Elsevier-North Holland, Amsterdam 1956, s. 53.

2 J. Szczepański, Konsumpcja a rozwój człowieka, Polskie Wydawnictwo Ekonomiczne, Warszawa 1981, s. 336.

3 L. von Bortkiewicz, Der Begriff „SOzialpolitik”, ,Jahrbücher für Nationalökonomie und Statistik” 1899, t. 17(72), nr 3, s. 332

4 Por. A. Szelągowska, Społeczne potrzeby mieszkaniowe a światowa teoria potrzeb [w:] Współczesne wyzwania dla lokalnej polityki społecznej, red. M. Gagacka, K. Głąbicka, Wydawnictwo Politechniki Radomskiej, Radom 2007, s. 45-57.
} 
niej rola regulatora. Rolę tę dobrze definiuje A. Kurzynowski, który politykę społeczną rozumie jako „działalność państwa, samorządu i organizacji pozarządowych zmierzającą do kształtowania ogólnych warunków pracy i bytu ludności, prorozwojowych struktur społecznych oraz stosunków społecznych opartych na równości i sprawiedliwości społecznej, sprzyjających zaspokajaniu potrzeb społecznych na dostępnym poziomie" ${ }^{\prime \prime}$. Dostępność w tym przypadku oznacza liczbę metrów kwadratowych mieszkania możliwych do wynajmu przy rynkowej stawce czynszu za przeciętne wynagrodzenie w danej miejscowości lub za pozostający do dyspozycji gospodarstwa domowego dochód rozporządzalny ${ }^{6}$. Ponieważ polityka społeczna jest częścią polityki gospodarczej, w funkcjonowaniu sfery mieszkaniowej jeszcze bardziej zauważalna staje się aktywna rola państwa jako regulatora. Interwencjonizm państwowy przejawia się właśnie w przyjęciu i realizowaniu określonej polityki mieszkaniowej w danym przedziale czasu. Stąd N. Acocella definiuje politykę gospodarczą jako dyscyplinę badającą publiczne działania gospodarcze na poziomie7:

- identyfikacji społecznych celów lub preferencji (np. zapewnienie mieszkań cudzoziemcom mającym status uchodźcy lub którym udzielono ochrony uzupełniającej, ofiarom przemocy w rodzinie, niepełnosprawnym, wychowankom domów dziecka, osobom, które straciły mieszkania w pożarze albo w wyniku powodzi itp.),

- "bieżących" wyborów dokonywanych przez państwo (np. zwiększenie wydatków na mieszkalnictwo, przydział bonów mieszkaniowych),

- wyborów dokonywanych przez instytucje wyższego szczebla (np. powołanie Funduszu Mieszkań na Wynajem ${ }^{8}$, Funduszu Sektora Mieszkań dla Rozwoju ${ }^{9}$ realizacja programu Mieszkanie Plus czy Mieszkanie na Start).

Polityka mieszkaniowa, będąca składową polityki społecznej i polityki gospodarczej, opiera się na przysługującym jednostce prawie do mieszkania. Prawo to, na co wskazuje A. Andrzejewski, stanowi rudymentarny fundament kształtowania stosunków międzyludzkich w społeczeństwie, realizacja zaś prawa jednostki do mieszkania powinna stanowić jeden z głównych celów polityki społecznej i gospodarczej w ramach ogólnych działań zmierzających do poprawy warunków bytowych i podniesienia poziomu życia społeczeństwa ${ }^{10}$. Należy zgodzić się z E. Kaltenberg-Kwiatkowską, która podkreśla, że prawo do posiadania przez człowieka godziwego, odpowiedniego mieszkania jest jedną z tych wartości społecznych, do których osiągnięcia ludzie powszechnie dążą, a których brak odczuwają jako deprywację ${ }^{11}$.

5 A. Kurzynowski, Zwiqzzki polityki społecznej z polityka gospodarcza [w:] Polityka społeczna, red. A. Kurzynowski, Oficyna Wydawnicza SGH, Warszawa 2001, s. 11. Więcej definicji polityki społecznej zaprezentował w swojej książce R. Szarfenberg, Krytyka i afirmacja polityki społecznej, Instytut Filozofii i Socjologii PAN, Warszawa 2008.

6 M. Bryx, A. Szelągowska, Rozwój zasobu mieszkań dostępnych w stolicy w perspektywie 2030 (ekspertyza dla Biura Polityki Lokalowej Urzędu Miasta Warszawy), Warszawa 2018, s. 7-8.

7 N. Acocella, Zasady polityki gospodarczej, PWN, Warszawa 2002, s. 16.

8 Więcej na ten temat na stronie: https://funduszmieszkan.pl/ [dostęp: 30 czerwca 2021 r.].

9 Więcej na ten temat na stronie: https://nieruchomosci.pfr.pl/inwestycje/fundusz-mieszkan-dla-rozwoju/ [dostęp: 30 czerwca 2021 r.].

10 A. Andrzejewski, Zarys polityki mieszkaniowej, Arkady, Warszawa 1969, s. 326.

11 E. Kaltenberg-Kwiatkowska, Społeczne problemy mieszkalnictwa i socjologia mieszkania [w:] Mieszkanie. Analiza socjologiczna, red. E. Kaltenberg-Kwiatkowska, Polskie Wydawnictwo Ekonomiczne, Warszawa 1982, s. 31. 
W wielu międzynarodowych aktach prawnych prawo do mieszkania opiera się na zapewnieniu każdemu człowiekowi warunków do godnego bytowania, zatem jest to prawo o charakterze socjalnym, mające status konstytucyjny, ale nie roszczeniowy ${ }^{12}$. Gdy uwzględnimy powyższe, przez prawo do mieszkania należy co do zasady rozumieć obowiązek władz publicznych tworzenia prawnych i faktycznych warunków do zaspokojenia potrzeb mieszkaniowych przez każdego człowieka w drodze trwałego i stabilnego korzystania z własnego lub cudzego mieszkania. Posiadanie mieszkania przekłada się na korzystanie z praw i wolności oraz wypełnianie obowiązków przez człowieka w państwie demokratycznym. W polskim prawodawstwie zaspokojenie potrzeb mieszkaniowych, a zatem także prawo do mieszkania, zostało podniesione do rangi konstytucyjnej. Przepisy art. 75 i 76 Konstytucji RP nałożyły na władze publiczne obowiązek podjęcia działań na rzecz urzeczywistnienia prawa do mieszkania. W artykułach tych wskazano wartości, które ustawodawca zwykły jest zobowiązany chronić. Chodzi tu o pomoc obywatelom w zaspokojeniu ich potrzeb mieszkaniowych, w tym o przeciwdziałanie bezdomności i ochronę praw lokatorów. W przeciwieństwie do prawa własności, które jest prawem negatywnym, zakazuje bowiem ingerencji, prawo do mieszkania ma charakter prawa pozytywnego, czyli prawa świadczącego ${ }^{13}$. Oznacza to, że nakłada ono na władze publiczne obowiązek prowadzenia zróżnicowanych polityk szczegółowych, które mają wspierać zaspokojenie potrzeb mieszkaniowych obywateli w możliwie najwyższym stopniu. Przepisy art. 75 Konstytucji RP, na co wskazuje L. Garlicki, dotyczą jednak wyłącznie osób fizycznych, tylko one mają bowiem potrzeby mieszkaniowe ${ }^{14}$. Ponadto polityka mieszkaniowa sprzyjająca zaspokajaniu potrzeb mieszkaniowych nie oznacza obowiązku dostarczenia każdemu obywatelowi mieszkania przez władze publiczne. Zadaniem władz publicznych jest wspieranie obywateli, a nie wyręczanie ich w staraniach o mieszkanie. Jak słusznie wskazuje A. Mączyński, w konstytucyjnym prawie do mieszkania nie wolno upatrywać źródła roszczenia przeciwko państwu o dostarczenie mieszkania ${ }^{15}$. Zadaniem państwa jest bowiem tworzenie warunków sprzyjających zaspokojeniu potrzeb mieszkaniowych przez obywateli w ich własnym zakresie.

Krajowa polityka mieszkaniowa jest w dużej mierze realizowana w ramach lokalnej (gminnej) polityki mieszkaniowej. W polskich warunkach zaspokajanie potrzeb mieszkaniowych należy do obowiązków samorządów lokalnych, o czym jest mowa w art. 7 ust. 1 ustawy z dnia 8 marca 1990 r. o samorządzie gminnym ${ }^{16}$ : „zaspokajanie zbiorowych potrzeb wspólnoty należy do zadań własnych gminy. W szczególności zadania własne obejmują sprawy [...] gminnego bu-

12 M. Florczak-Wątlor, Obowiq̨zek ochrony beneficjentów prawa do mieszkania jako "innego prawa majątkowego" w rozumieniu art. 64 ust. 1 i 2 Konstytucji RP, "Gdańskie Studia Prawnicze” 2018, t. 40, s. 169.

13 S. Jarosz-Żukowska, Przedmiot i specyfika ochrony własności w przepisach konstytucyjnych - ujęcie polskie na tle porównawczym , „Prace Naukowe Wydziału Prawa, Administracji i Ekonomii Uniwersytetu Wrocławskiego" 2017, nr 92 [Własność w prawie i gospodarce, red. U. Kalina-Prasznic], s. 34.

14 L. Garlicki, Komentarz do art. 75 [w:] Konstytucja RP. Komentarz, t. III, red. L. Garlicki, Wydawnictwo Sejmowe, Warszawa 2003, s. 5.

15 A. Mączyński, Prawo do mieszkania w świetle Konstytucji RP [w:] Godność człowieka a prawa ekonomiczne i socjalne. Księga jubileuszowa wydana w piętnasta rocznicę ustanowienia Rzecznika Praw Obywatelskich, Biuro Rzecznika Praw Obywatelskich, Warszawa 2003, s. 136.

16 Dz.U. 2020, poz. 713, ze zm. 
downictwa mieszkaniowego". Słowa te znalazły swoje potwierdzenie 11 lat później w ustawie z dnia 21 czerwca 2001 r. o ochronie praw lokatorów, mieszkaniowym zasobie gminy i o zmianie Kodeksu cywilnego ${ }^{17}$. Zgodnie z jej art. 4 ust. 1, 2 i 3 „tworzenie warunków do zaspokajania potrzeb mieszkaniowych wspólnoty samorządowej należy do zadań własnych gminy. Gmina, na zasadach i w przypadkach określonych w ustawie, zapewnia lokale w ramach najmu socjalnego i lokale zamienne, a także zaspokaja potrzeby mieszkaniowe gospodarstw domowych o niskich dochodach. [...] Gmina wykonuje powyższe zadania, wykorzystując mieszkaniowy zasób gminy lub w inny sposób". Kluczowe znaczenie w realizacji współczesnej polityki mieszkaniowej ma przyjęty uchwałą nr 115/2016 Rady Ministrów w dniu 27 września 2016 r. Narodowy Program Mieszkaniowy ${ }^{18}$. Dokument ten określa kierunki polityki mieszkaniowej państwa i jej główne cele, które mają być osiągnięte do 2030 r. i do których należą:

- wzrost liczby mieszkań na 1000 mieszkańców do poziomu odpowiadającego aktualnej średniej dla Unii Europejskiej - celem jest zwiększenie dostępu do mieszkań dla osób o dochodach uniemożliwiających nabycie lub wynajęcie mieszkania na zasadach komercyjnych;

- uzyskanie przez samorządy możliwości zaspokojenia potrzeb mieszkaniowych wszystkich osób zagrożonych wykluczeniem społecznym ze względu na niskie dochody lub szczególnie trudną sytuację życiową, oczekujących na najem gminnego lokalu;

- obniżenie liczby osób mieszkających w warunkach substandardowych (m.in. zły stan techniczny budynku, przeludnienie, brak podstawowych instalacji technicznych) o 2 mln osób (z ok. 5,3 mln do ok. 3,3 mln).

Szerzej na temat Narodowego Programu Mieszkaniowego będzie mowa w ostatnim punkcie tego artykułu.

\section{Cele polityki mieszkaniowej}

Cele polityki mieszkaniowej - jako polityki sektorowej - powinny być sprzężone z celami polityki gospodarczej państwa. Oznacza to, że rezultaty prowadzonej polityki mieszkaniowej są determinowane głównie przez narzędzia i instrumenty polityki ekonomicznej, fiskalnej i pieniężnej. Załamanie na rynku mieszkaniowym negatywnie oddziałuje na tempo wzrostu gospodarczego i przekłada się na stan sektorów okołomieszkaniowych (czyli takich, których dobra i usługi są nieodzowne do zapewnienia odpowiedniej jakości zasobów mieszkaniowych). Istniejące sprzężenie zwrotne między polityką mieszkaniową a polityką gospodarczą wymaga skoordynowania wielu narzędzi, umożliwiających stabilny i zrównoważony rozwój rynku oraz przeciwdziałających występowaniu kryzysów gospodarczych lub sektorowych. Podstawowe cele polityki mieszkaniowej, na co wskazuje P. Lis, powinny opierać się na stronie popytowo-podażowej, tj.:

- cele dotyczące strony popytowej ogniskują się na tworzeniu warunków do nabycia lub najmu mieszkań przez wszystkich zainteresowanych;

17 Dz.U. 2020, poz. 611, ze zm.

18 Uchwała nr 115/2016 Rady Ministrów z dnia 27 września 2016 r. w sprawie przyjęcia Narodowego Programu Mieszkaniowego (RM-111-119-16), https://www.gov.pl/web/rozwoj-praca-technologia/narodowy-program-mieszkaniowy [dostęp: 30 czerwca 2021 r.]. 
- cele dotyczące strony podażowej koncentrują się na zapewnieniu dostępności zasobu mieszkaniowego i utrzymaniu odpowiedniej jakości tego zasobu ${ }^{19}$.

Głównym celem polityki mieszkaniowej jest poprawa warunków mieszkaniowych gospodarstw domowych. Jak wskazują V. Polakow i C. Guillean, można go zrealizować przez zapewnienie mieszkań osobom najbardziej potrzebującym. Ważne jest przy tym zróżnicowanie pod względem zamożności lokatorów korzystających z mieszkań na wynajem, tak by nie tworzyć gett dla najbiedniejszych i nie narażać ich na wykluczenie społeczne ${ }^{20}$.

W dokumencie Założenia polityki wsparcia mieszkalnictwa do 2020 roku ${ }^{21}$ za podstawowe cele realizowanej w Polsce w latach 2011-2020 polityki mieszkaniowej uznano:

- likwidację deficytów ilościowych w segmencie mieszkań socjalnych²2 i wsparcie osób wymagających innej społecznej pomocy mieszkaniowej;

- eliminację podstawowych rodzajów ryzyka związanego z rozwojem prywatnego budownictwa mieszkań na wynajem;

- wprowadzenie zróżnicowanych form podaży mieszkań dostępnych cenowo w segmencie mieszkań na wynajem oraz budownictwie własnościowym, umożliwiających najem mieszkania z mieszkaniowego zasobu gminy lub dojście przez gospodarstwa domowe do własności przez zakup mieszkania po przystępnych cenach;

- likwidację luki remontowej, rozumianej jako różnica pomiędzy środkami gromadzonymi na funduszu remontowym wspólnoty mieszkaniowej (lub spółdzielni) a nakładami finansowymi niezbędnymi do utrzymania nieruchomości w stanie niepogorszonym; brak nakładów na remonty zasobów mieszkaniowych powoduje ich dekapitalizację ${ }^{23}$ i niszczenie;

- obniżenie kosztów budowy zasobów mieszkaniowych i racjonalizację przestrzenno-funkcjonalną nowych mieszkań przez stworzenie odpowiedniego zasobu uzbrojonych gruntów pod budownictwo mieszkaniowe;

- ograniczenie zapotrzebowania na energię w sektorze mieszkaniowym przez stosowanie ekoinnowacyjnych rozwiązań.

Spośród powyższych założeń udało się zrealizować tylko drugie i trzecie. Pozostałe nadal są wyzwaniem w obszarze współczesnej polityki mieszkaniowej. Skuteczna polityka mieszkaniowa powinna stwarzać instrumenty aktywnego współdziałania i powinna mieć wpływ na decyzje podejmowane w sferze mieszkalnictwa. Decyzje te są determinowane z jednej strony wielkością

19 P. Lis, Polityka państwa w zakresie finansowania inwestycji mieszkaniowych, C.H. Beck, Warszawa 2008, s. 21.

20 International Perspectives on Homeless, red. V. Polakow, C. Guillean, Greenwood Press, Westport 2001, s. 11.

21 bip.mi.gov.pl/pl/bip/projekty_aktow_prawnych/projekty_ustaw/ustawy_mieszkalnictwo_i_gospodarka_komunalna/bs_mieszk2020/px_zasady_krm.pdf [dostęp: 14 marca 2021 r.], s. 12.

22 Zgodnie z definicją zawartą w ustawie z dnia 21 czerwca 2001 r. o ochronie praw lokatorów, mieszkaniowym zasobie gminy i o zmianie Kodeksu cywilnego (Dz.U. 2020, poz. 611, ze zm.) lokal socjalny to lokal nadający się do zamieszkania ze względu na wyposażenie i stan techniczny, którego powierzchnia pokoi przypadająca na członka gospodarstwa domowego najemcy nie może być mniejsza niż $5 \mathrm{~m}^{2}$, a w przypadku jednoosobowego gospodarstwa domowego - $10 \mathrm{~m}^{2}$. Sektor mieszkań socjalnych to zasoby mieszkaniowe gminy, w skład których wchodzą lokale socjalne.

23 Szacuje się, że ok. 1 mln mieszkań w Polsce należy wyburzyć ze względu na ich zły stan techniczny i nieracjonalność ekonomiczną ewentualnych nakładów na ich remont. 
niedoboru mieszkań, a z drugiej - poziomem zamożności społeczeństwa oraz wielkością potencjalnego wsparcia ze środków publicznych. Stosowane w Polsce instrumenty wsparcia mieszkalnictwa podlegały znaczącym zmianom od lat 90 . XX w. i obejmowały rozwiązania zmierzające do: - zwiększenia dostępności mieszkań ${ }^{24}$ dla najuboższych przez wspieranie realizacji inwestycji związanych z powiększaniem zasobu lokali socjalnych oraz miejsc w budynkach dla osób bezdomnych (segment budownictwa socjalnego);

- zwiększenia dostępności mieszkań dla osób niezamożnych i średniozamożnych, a także dla tzw. grup specjalnych (osoby starsze, osoby niepełnosprawne, imigranci), przez wspieranie realizacji mieszkań społecznych czynszowych, spółdzielczych lokatorskich oraz mieszkań chronionych (segment budownictwa społecznego) ${ }^{25}$;

- zwiększenia dostępności mieszkań dla osób zainteresowanych własnością mieszkaniową przez wspieranie pozyskiwania źródeł finansowania oraz możliwość odzyskania części wydatków poniesionych na zakup lub budowę mieszkania (budownictwo własnościowe) ${ }^{26}$;

- poprawy stanu technicznego zasobów mieszkaniowych przez wspieranie inwestycji termomodernizacyjnych i remontowych (cały zasób) ${ }^{27}$;

- stopniowej redukcji zobowiązań państwa z poprzednich okresów przez wypłatę premii gwarancyjnych, wykup odsetek od tzw. starych kredytów spółdzielczych, a także zrekompensowanie właścicielom utraconych możliwości dochodowych w wyniku obowiązywania czynszów regulowanych ${ }^{28}$.

Skala stosowanego instrumentarium polityki mieszkaniowej była i jest uzależniona nie tylko od bezpośredniej pomocy państwa, lecz także od możliwości finansowych samorządów lokalnych, na które scedowano zadanie zaspokajania potrzeb mieszkaniowych.

\section{Ocena współczesnych potrzeb mieszkaniowych w Polsce}

Diagnoza rzeczywistych, zagregowanych potrzeb mieszkaniowych i zgłaszanego przez indywidualne gospodarstwa domowe zapotrzebowania mieszkaniowego jest wciąż kluczowym wyzwaniem polityki mieszkaniowej państwa. Potrzeby gospodarstw domowych w tym względzie są nieograniczone i ulegają zmianie wraz ze wzrostem ich zamożności, co sprawia, że są one trudno mierzalne. Podejmowane są jednak próby skwantyfikowania potrzeb mieszkaniowych

24 Przez dostępność mieszkań rozumie się stosunek przeciętnych dochodów rozporządzalnych gospodarstw domowych z różnych grup społeczno-ekonomicznych do cen mieszkań na rynku pierwotnym i wtórnym oraz wysokości czynszów najmu mieszkań w różnych typach zasobów mieszkaniowych.

25 Szerzej na ten temat w: A. Szelągowska, Koncepcja programu Mieszkanie dla Młodych a kwestia mieszkaniowa w Polsce, „Prace Naukowe Wyższej Szkoły Bankowej w Gdańsku” 2013, t. 27, s. 251-259.

26 Szerzej na ten temat w: A. Szelągowska, Program „Rodzina na swoim” jako instrument polityki mieszkaniowej rządu stymulujqcy popyt na kredyty mieszkaniowe [w:] Współczesna bankowość hipoteczna, red. A. Szelągowska, CeDeWu, Warszawa 2010, s. 69-83.

27 https://www.bgk.pl/programy-i-fundusze/fundusze/fundusz-termomodernizacji-i-remontow-ftir/ [dostęp: 30 czerwca 2021 r.].

28 Szerzej na ten temat w: A. Szelągowska, Finansowanie społecznego budownictwa mieszkaniowego, CeDeWu, Warszawa 2011, s. 291-294. 
w celu szacunkowej oceny liczby mieszkań niezbędnych do zaspokojenia podstawowych potrzeb mieszkaniowych gospodarstw domowych, których nie stać na zakup własnej nieruchomości mieszkaniowej lub wynajem mieszkania po cenach rynkowych. Najczęściej stosowanym na świecie wskaźnikiem służącym do oceny liczby brakujących na rynku zasobów mieszkaniowych jest statystyczny deficyt mieszkaniowy, obliczany jako różnica między całkowitą liczbą istniejących zasobów mieszkaniowych ${ }^{29}$ (zamieszkanych i niezamieszkanych) a liczbą gospodarstw domowych.

Gdyby zastosować tę miarę, należałoby przyjąć, że według Głównego Urzędu Statystycznego (GUS) w Polsce od 2013 r. mieszkań nie brakuje, a nawet jest ich zauważalnie więcej niż gospodarstw domowych ${ }^{30}$. Zgodnie z dostępnymi danymi GUS na dzień 30 kwietnia 2021 r. w Polsce w 2019 r. odnotowano nadwyżkę zasobów mieszkaniowych nad liczbą gospodarstw domowych, która na koniec 2019 r. wyniosła 424 tys. mieszkań, co oznaczałoby rosnącą liczbę pustostanów $^{31}$. Jednakże jeśli uwzględni się liczbę faktycznie zamieszkanych zasobów mieszkaniowych, według szacunków Ministerstwa Rozwoju na koniec 2019 r. statystyczny deficyt mieszkaniowy wynosił 641 tys. mieszkań, a więc ok. 4,5\% gospodarstw domowych w Polsce zamieszkiwało niesamodzielnie (co było jednak najniższym wynikiem w historii pomiarów) ${ }^{32}$. Jednocześnie udział osób młodych - w wieku od 25 do 34 lat - które mieszkały wspólnie z rodzicami, wynosił w Polsce w 2019 r. 45,1\% (przy średniej dla UE na poziomie 28,6\%) ${ }^{33}$.

Przy uwzględnieniu powyższych rozbieżnych danych statystycznych deficyt mieszkaniowy, chociaż to wskaźnik stosowany przez urzędy statystyczne na świecie, nie jest zdaniem autorki w pełni miarodajnym narzędziem do oceny luki mieszkaniowej ani na szczeblu gminnym, ani na szczeblu krajowym. Statystyczny deficyt mieszkaniowy nie odzwierciedla faktycznego zapotrzebowania na mieszkania w skali kraju, tylko prezentuje dane szacunkowe. Poza tym dane urzędów statystycznych nie są wolne od błędu i odbiegają od stanu rzeczywistego, zmienność wielu parametrów w ciągu roku powoduje bowiem utrudnienia w precyzyjnym określeniu wielkości tego wskaźnika (dotyczy to także liczby gospodarstw domowych rozumianych jako zespół osób, spokrewnionych lub niespokrewnionych, wspólnie zamieszkujących i się utrzymujących). Trudności w określeniu faktycznego deficytu mieszkaniowego wynikają, po pierwsze, ze zbyt

29 Według definicji GUS zasoby mieszkaniowe stanowią ogół mieszkań zamieszkanych i niezamieszkanych znajdujących się w budynkach mieszkalnych i niemieszkalnych. Do zasobów mieszkaniowych nie zalicza się lokali w obiektach zbiorowego zakwaterowania (tj. hoteli pracowniczych, domów studenckich, burs i internatów, domów pomocy społecznej), z wyjątkiem znajdujących się tam mieszkań, pomieszczeń prowizorycznych oraz obiektów ruchomych (tzn. barakowozów, wagonów kolejowych, barek i statków).

30 Według danych GUS na koniec 2013 r. statystyczna nadwyżka mieszkań nad liczbą gospodarstw domowych wynosiła 24 tys., w 2016 r. - 186 tys., w 2018 r. - 340 tys.

31 Według najnowszych dostępnych danych GUS na koniec 2018 r. w Polsce było 54206 pustostanów. Rozumie się przez nie mieszkanie, w którym w momencie badania statystycznego nie była zameldowana (na pobyt stały lub czasowy) żadna osoba ani nie mieszkała, nawet czasowo, żadna osoba bez zameldowania. W porównaniu z 2003 r. liczba pustostanów w Polsce wzrosła dwuipółkrotnie, a w porównaniu z 2009 r. o 80\%; https://bdl.stat.gov.pl/BDL/dane/podgrup/tablica [dostęp: 30 czerwca 2021 r.].

32 Ministerstwo Rozwoju, Raport. Stan mieszkalnictwa w Polsce, Warszawa 2020, s. 9.

33 Ibidem. 
rzadko przeprowadzanych spisów powszechnych - ostatni spis powszechny odbył się w 2011 r. $^{34}$, a w kwietniu 2021 r. rozpoczęto kolejny spis. Po drugie, wątpliwości nasuwają się podczas analizy udostępnianych przez urzędy statystyczne danych o wielkości zasobów mieszkaniowych na koniec danego roku (nie podaje się np. liczby zasobów mieszkaniowych, które ze względu na zły stan techniczny nie nadają się do użytkowania, a są nadal zamieszkiwane, choć stwarza to zagrożenie dla życia i zdrowia; nie uwzględnia się również pustostanów, budynków rekreacji indywidualnej ${ }^{35}$, które także częstokroć są zamieszkiwane całorocznie). W świetle powyższych rozważań należy podkreślić, że ustalanie celów polityki mieszkaniowej na podstawie statystycznego deficytu mieszkaniowego nie jest satysfakcjonującym rozwiązaniem, jednak na razie jest to jedyny wskaźnik powszechnie stosowany na świecie w celu pokazania różnicy między istniejącym zasobem mieszkaniowym a liczbą gospodarstw domowych.

Zdaniem autorki jednym z rozwiązań, które mogłyby pomóc w ocenie liczby gospodarstw domowych wykorzystywanej do obliczenia statystycznego deficytu mieszkaniowego, byłoby wdrożenie systemu monitorującego aktualny adres pobytu/zamieszkania obywateli wzorowanego na rozwiązaniach stosowanych w Szwecji. Każdy może sprawdzić w internecie, pod jakim adresem przebywa jakakolwiek osoba mieszkająca w Szwecji. Dane te są dostępne na stronach: www.hitta.se albo www.eniro.se. Można też zwrócić się o pomoc do dowolnego szwedzkiego urzędu skarbowego, który prowadzi centralną ewidencję ludności (www.skatteverket.se), albo poszukać na stronie www.birthday.se/sok/ - wystarczy znać imię i nazwisko oraz datę urodzenia danej osoby. Według wiedzy autorki Szwecja to jedyne państwo UE, które umożliwia powszechny dostęp osób trzecich do takich danych osobowych. Dzięki temu rozwiązaniu nie ma problemu z określeniem miejsca pobytu swoich obywateli ani kierowaniem pomocy społecznej do osób, które jej potrzebują ${ }^{36}$.

Dla porównania w Polsce, według danych Ministerstwa Cyfryzacji, w okresie od stycznia do października 2020 r. 508 tys. Polaków zmieniło adres zameldowania i podało urzędom nowy adres zamieszkania. Z tej grupy 9,6 tys. osób wymeldowało się z Polski - jako powód wskazywano wyjazd za granicę. Jednakże aż 244,4 tys. osób wnioskujących o wymeldowanie nie podało żadnego innego adresu w Polsce, mimo że formalnie obowiązek meldunkowy wciąż obowiązuje ${ }^{37}$.

34 Z ostatnich najbardziej wiarygodnych danych o liczbie gospodarstw domowych, które posiada GUS i które pochodzą z Narodowego Spisu Powszechnego Ludności i Mieszkań z 2011 roku, wynika, że w Polsce dekadę temu było 13,572 mln gospodarstw domowych.

35 Na budowę budynków rekreacji indywidualnej, zwanych domkami letniskowymi, których powierzchnia zabudowy nie przekracza $35 \mathrm{~m}^{2}$, nie trzeba mieć zezwolenia. Szacunki Open Finance wskazują, że w Polsce w 2020 r. było ponad 320 tys. takich obiektów; https://www.muratorplus.pl/biznes/prawo/budynek-rekreacji-indywidualnej-jakie-warunki-budowy-domku-letniskowego-aa-iKCk-YBr1-eHTk.html [dostęp: 30 czerwca 2021 r.].

36 Według danych organizacji Sveriges Allmännytta jedna trzecia mieszkańców Szwecji mieszka w wynajmowanych mieszkaniach, z czego co siódmy mieszkaniec Szwecji wynajmuje mieszkanie komunalne. Mniej więcej połowa tych mieszkań jest własnością spółek komunalnych, a druga połowa należy do prywatnych właścicieli; https://www.sverigesallmannytta.se/ [dostęp: 30 czerwca 2021 r.].

37 https://www.money.pl/gospodarka/coraz-wiecej-polakow-wymeldowuje-sie-z-kraju-polityka-podatkowa-rzadu-ulatwia-im-decyzje-6573874458864512a.html [dostęp: 30 czerwca 2021 r.]. 
To pokazuje skalę problemu oszacowania rzeczywistej liczby gospodarstw domowych oraz trudności w zlokalizowaniu obywateli przez różnego rodzaju urzędy i instytucje (sądy, urzędy skarbowe, banki, firmy pożyczkowe, zakłady ubezpieczeń, komorników). Według danych Ministerstwa Cyfryzacji na dzień 24 stycznia 2021 r. na pobyt stały w Polsce było zameldowanych 36,53 mln osób. Zgodnie z najnowszymi danymi GUS o liczbie ludności na koniec czerwca 2020 r. w Polsce mieszkało 38,35 mln osób ${ }^{38}$. Różnica między liczbą ludności Polski a liczbą osób zameldowanych na pobyt stały wynosiła 1,82 mln osób. Oznacza to, że 4,7\% ludności Polski nie posiadało stałego zameldowania.

O skali współczesnych potrzeb mieszkaniowych świadczą również dane z raportu Najwyższej Izby Kontroli (NIK) na temat skuteczności działań administracji publicznej na rzecz zaspokajania potrzeb mieszkaniowych osób o niskich dochodach ${ }^{39}$. Kontrola dotyczyła działań gmin w okresie od stycznia 2016 do czerwca 2019 r. realizowanych w ramach zadań własnych, jak również z wykorzystaniem środków finansowych budżetu państwa przeznaczonych na budownictwo komunalne. Z przeprowadzonych przez NIK analiz wynika, że liczba gospodarstw domowych oczekujących na mieszkanie gminne w analizowanym okresie wzrosła o 30\%, a maksymalny czas czekania na lokale socjalne wynosił 12 lat, natomiast na lokale komunalne - 17 lat. Według danych GUS na koniec 2019 r. na wynajem lokali z mieszkaniowego zasobu gmin oczekiwało 150579 gospodarstw domowych, włączając w to 81214 gospodarstw domowych oczekujących na wynajem lokalu socjalnego (w tym w ramach realizacji wyroków eksmisyjnych 47644 gospodarstwa domowe) oraz 17871 gospodarstw domowych oczekujących na wynajem tymczasowych pomieszczeń ${ }^{40}$. Na koniec 2019 r. liczba zasobów mieszkaniowych gmin, na które obowiązywały umowy na wynajem ( $z$ wyłączeniem lokali zamiennych i tymczasowych pomieszczeń ${ }^{41}$ ), wyniosła $641801^{42}$. W tej liczbie było 73970 lokali mieszkalnych z komunalnych zasobów mieszkaniowych, na które obowiązywały na koniec 2019 r. umowy najmu socjalnego, oraz 1600 tymczasowych pomieszczeń, na które gminy miały zawarte umowy najmu³. W latach 2011-2019 liczba zasobów mieszkaniowych gmin zmniejszyła się o 41\%, a ich udział w łącznej liczbie krajowych zasobów mieszkaniowych obniżył się z 8\% do 4,3\%. Był to efekt sukcesywnej prywatyzacji zasobów,

38 Główny Urząd Statystyczny, Ludność. Stan i struktura ludności oraz ruch naturalny w przekroju terytorialnym. Stan w dniu 30 czerwca 2020, Warszawa 2021, s. 8.

39 Najwyższa Izba Kontroli, Informacja o wynikach kontroli. Działania administracji publicznej na rzecz zaspokajania potrzeb mieszkaniowych gospodarstw domowych o niskich dochodach. 16/2020/P/19/033/KIN, Warszawa 2020, https://www.nik.gov.pl/aktualnosci/lokale-socjalne-i-komunalne.html [dostęp: 30 czerwca 2021 r.].

40 Główny Urząd Statystyczny, Gospodarka mieszkaniowa i infrastruktura komunalna w 2019 r., Warszawa 2020, s. 10.

41 Pomieszczenie tymczasowe jest definiowane jako pomieszczenie, które nadaje się do zamieszkania, posiada dostęp do źródła zaopatrzenia w wodę i do ustępu (nawet jeśli te urządzenia znajdowałyby się poza budynkiem), oświetlenie naturalne i elektryczne, możliwość ogrzewania, niezawilgocone przegrody budowlane oraz umożliwia zainstalowanie urządzenia do gotowania posiłków, zapewnia co najmniej $5 \mathrm{~m}^{2}$ powierzchni mieszkalnej na jedną osobę i w miarę możności znajduje się w tej samej lub pobliskiej miejscowości, w której dotychczas zamieszkiwały osoby przekwaterowywane.

42 Główny Urząd Statystyczny, Gospodarka mieszkaniowa..., s. 17.

43 Ibidem, s. 18. 
wyłączenia lokali z użytkowania z powodu złego stanu technicznego oraz niskiego tempa pozyskiwania nowych lokali.

Pomimo spadku liczby lokali w komunalnych zasobach mieszkaniowych i rosnącej liczby osób oczekujących na te lokale w zasobach gmin w połowie 2019 r. pozostawało nadal 49,5 tys. pustostanów ${ }^{44}$. Stan techniczny komunalnych zasobów mieszkaniowych sukcesywnie się pogarsza. Wpływ ma na to brak środków finansowych na przeprowadzenie remontów mieszkań komunalnych. Z raportu Instytutu Rozwoju Miast i Regionów wynika, że w 2016 r. 46\% badanych miast nie wykonało żadnych gruntownych remontów w swoich zasobach mieszkaniowych, $21 \%$ - nie przeprowadziło żadnego remontu, a 17\% gminnych zasobów mieszkaniowych pozostawało w złym stanie technicznym ${ }^{45}$. Za jedną z głównych przyczyn tego stanu uznano m.in. niskie stawki czynszów, które nie wystarczały na pokrycie kosztów eksploatacyjnych zasobu, oraz zaległości czynszowe lokatorów ${ }^{46}$. W złym stanie technicznym są jednak nie tylko lokale komunalne. Z raportu NIK wynika, że ok. 10\% Polaków mieszka w lokalach przeludnionych i w złym stanie technicznym ${ }^{47}$, chociaż od lat stan techniczny krajowych zasobów mieszkaniowych stopniowo się poprawia. Według danych GUS na koniec 2019 r. w instalację wodociągową było wyposażonych 96,9\% mieszkań, w ustęp - 93,9\%, w łazienkę - 91,7\%, a w instalację gazową - 56\% mieszkań ${ }^{48}$. O stanie technicznym zasobów mieszkaniowych świadczy wskaźnik deprywacji mieszkaniowej, który obrazuje procentowy udział populacji mieszkającej w mieszkaniach substandardowych z powodu: przeciekającego dachu, zawilgocenia ścian, fundamentów, butwiejących ram drzwi i okien lub podłóg, braku wanny lub prysznica w mieszkaniu, braku toalety wewnątrz budynku do wyłącznego korzystania przez gospodarstwo domowe oraz zbyt ciemnego mieszkania. Według danych Eurostatu w 2019 r. wskaźnik deprywacji mieszkaniowej wynosił w Polsce 10,8\% (utrzymuje się on w okresie ostatnich dziewięciu lat na średnim poziomie $11 \%)$, przy średniej unijnej $13,1 \%{ }^{49}$.

W Polsce w 2019 r. na 1000 mieszkańców przypadało zaledwie 390 mieszkań, co w porównaniu z 2010 r. oznaczało wzrost o 11,1\% (349,6 mieszkań) ${ }^{50}$. W ponad połowie państw członkowskich UE w 2019 r. na 1000 mieszkańców przypadało ponad 500 mieszkań51. Wskaźnik ten był najwyższy w państwach, w których gospodarka opiera się na turystyce i w których domy wakacyjne zaburzają statystyki, przez co nie odzwierciedlają faktycznych społecznych potrzeb mieszkaniowych. Jednakże przy uwzględnieniu celu sformułowanego w Narodowym Programie

44 Najwyższa Izba Kontroli, op. cit., s. 5.

45 Raport o stanie polskich miast. Mieszkalnictwo społeczne, red. A. Muzioł-Węcławowicz, K. Nowak, Instytut Rozwoju Miast i Regionów, Warszawa 2018, s. 25.

46 Według danych GUS na koniec 2018 r. łączne zaległości lokatorów w opłatach za mieszkania w zasobach gminnych wynosiły 4,18 mld zł; https://bdl.stat.gov.pl/BDL/dane/podgrup/tablica [dostęp: 30 czerwca 2021 r.].

47 Najwyższa Izba Kontroli, op. cit., s. 5.

48 Główny Urząd Statystyczny, Gospodarka mieszkaniowa..., s. 15.

49 https://appsso.eurostat.ec.europa.eu/nui/show.do?dataset=ilc_mdho01\&lang=en [dostęp: 30 czerwca 2021 r.].

50 https://sdg.gov.pl/statistics_nat/1-4-a/ [dostęp: 30 czerwca 2021 r.].

51 https://www.oecd.org/els/family/HM1-1-Housing-stock-and-construction.pdf [dostęp: 30 czerwca 2021 r.]. 
Mieszkaniowym, dotyczącego zrównania liczby mieszkań przypadających na 1000 mieszkańców ze średnią unijną, oznaczałoby to, że do 2030 r. w Polsce powinno powstać co najmniej 4,19 mln mieszkań, jeśli założymy, że liczba mieszkańców będzie wynosić 38 mln osób ${ }^{52}$ (a średnia unijna pozostanie na aktualnym poziomie 500 mieszkań). Oznaczałoby to, że średniorocznie w Polsce należałoby oddawać do 2030 r. 466 tys. mieszkań, aby wskaźnik ten zrównał się ze średnią unijną (o ile nie wzrośnie ona w UE do 2030 r.). Według danych GUS w całym 2020 r. oddano do

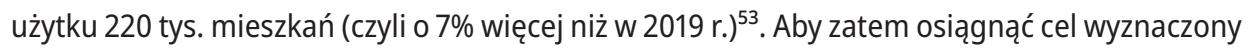
w Narodowym Programie Mieszkaniowym, średniorocznie w Polsce należałoby oddawać do użytkowania co najmniej dwukrotnie więcej mieszkań niż w rekordowym pod tym względem 2020 r. Ostatni raz liczba 200 tys. mieszkań oddanych do użytku została przekroczona w 1980 r., a najwyższy wskaźnik 284 tys. mieszkań oddanych do użytku zanotowano w latach 1978 i 1979. Wątpliwe jest zatem, zdaniem autorki, by kiedykolwiek do 2030 r. udało się pobić rekord z końca lat 70. XX w.

Zdaniem autorki lepszym wskaźnikiem pomocnym w ocenie zaspokajania zgłaszanych potrzeb mieszkaniowych byłby wskaźnik zaspokojenia społecznych potrzeb mieszkaniowych, obliczany jako iloraz liczby oddawanych co roku do użytku mieszkań (nowych, pozyskanych, odzyskanych i wyremontowanych) o przystępnych czynszach ${ }^{54}$ do łącznej liczby gospodarstw domowych oczekujących w skali kraju na przydział mieszkania. Przy czym liczba gospodarstw domowych oczekujących na mieszkanie o przystępnym czynszu uwzględniałaby zarówno ludzi oczekujących na przydział lokalu z komunalnego zasobu gminy, jak i osoby, które nie kwalifikują się do wynajmu mieszkania komunalnego, socjalnego, pomieszczenia zastępczego itp., choć nie stać ich na wynajem mieszkania po cenach rynkowych lub nie mają zdolności kredytowej na zakup własnego mieszkania i z tego powodu zgłaszają chęć wynajmu lokalu gminnego. Pomocnym narzędziem byłaby tu ogólnokrajowa baza danych o liczbie gospodarstw domowych oczekujących na mieszkanie o przystępnym czynszu z podziałem na województwa, powiaty i gminy. Baza taka powinna jednocześnie zawierać informacje o liczbie zasobów mieszkaniowych będących w dyspozycji gmin oraz o ich stanie, a także o planowanych do oddania zasobach mieszkaniowych w perspektywie najbliższych 12 miesięcy - zarówno nowych, jak i wyremontowanych (ze wskazaniem ich stanu, liczby pokoi i kondygnacji, wysokości czynszu itp.).

Innym wskaźnikiem odzwierciedlającym efekty polityki mieszkaniowej państwa mógłby być wskaźnik dostępności mieszkań o przystępnych czynszach obliczany jako iloraz całkowitej liczby mieszkań o przystępnych czynszach do łącznej liczby gospodarstw domowych oczekujących na przydział mieszkania o przystępnym czynszu. Główną zaletą takiego miernika byłaby prezentacja rezultatów polityki mieszkaniowej państwa kierowanej do najbardziej potrzebujących osób. Lepiej przedstawiałby także postępy w zaspokajaniu potrzeb mieszkaniowych gospodarstw

52 Oczywiście założenie dotyczące utrzymania populacji na niezmienionym poziomie jest obarczone błędem, ponieważ prognozy wskazują na systematyczne zmniejszanie się liczby ludności Polski w kolejnych dekadach.

53 Główny Urząd Statystyczny, Budownictwo mieszkaniowe w okresie I-XII 2020 r. Informacja sygnalna, Warszawa 2021, s. 1.

54 Szerzej na temat przystępnych (umiarkowanych) czynszów w: M. Bryx, A. Szelągowska, op. cit., s. 10-17. 
domowych oczekujących na najem mieszkania o przystępnym czynszu w poszczególnych regionach Polski. Jednocześnie ten wskaźnik i wcześniejszy zaproponowany przez autorkę mogłyby także posłużyć deweloperom chcącym realizować niskoczynszowe inwestycje mieszkaniowe pod wynajem na terenach konkretnych gmin. Wskaźnik dostępności mieszkań o przystępnych czynszach mógłby również wskazywać różnice w poziomie czynszów na lokalnym rynku najmu, a wspomniana wyżej ogólnokrajowa baza danych o liczbie gospodarstw domowych oczekujących na mieszkanie o przystępnym czynszu z podziałem na województwa, powiaty i gminy mogłaby pomóc w alokacji zasobów siły roboczej. Zaproponowane przez autorkę wskaźniki lepiej ukazywałyby stopień zaspokojenia potrzeb mieszkaniowych niż wskaźnik nasilenia budownictwa mieszkaniowego, wyrażony liczbą mieszkań oddanych do użytkowania w przeliczeniu na 1000 mieszkańców, wynoszący w 2020 r. w Polsce 5,855.

\section{Cele, instrumenty i wyzwania współczesnej polityki mieszkaniowej państwa}

Pandemia wywołana COVID-19 odcisnęła piętno na każdym sektorze gospodarki i znacznie spowolniła wdrożenie wielu planów gospodarczych rządu. Covidyzacja gospodarki oddziałuje również na politykę mieszkaniową państwa. Jednostki samorządu terytorialnego, na których spoczywa obowiązek zaspokajania potrzeb mieszkaniowych, zostały szczególnie dotknięte skutkami pandemii w postaci wzrostu wydatków i znacznego spadku ich dochodów własnych. Realizacja założeń przedstawionych w Narodowym Programie Mieszkaniowym z pewnością przesunie się w czasie na IV dekadę XXI w. Kryzys wywołany koronawirusem zdaniem autorki uniemożliwi osiągnięcie celów sformułowanych w Narodowym Programie Mieszkaniowym do 2030 r. Jak już wcześniej wskazano, nie ma możliwości zrealizowania głównego celu polegającego na zwiększeniu dostępu do mieszkań dla osób o dochodach uniemożliwiających nabycie lub wynajęcie lokalu na rynku komercyjnym. Zastosowany wskaźnik nasilenia budownictwa mieszkaniowego jest nieodpowiedni, ponieważ dotyczy wzrostu liczby mieszkań przypadających na 1000 mieszkańców do wysokości mieszczącej się w aktualnej średniej dla Unii Europejskiej. Wzrost liczby mieszkań przypadających na 1000 mieszkańców nie odzwierciedla bowiem zaspokojenia potrzeb mieszkaniowych osób o dochodach uniemożliwiających nabycie lub wynajęcie mieszkania na zasadach komercyjnych. O wiele lepszym wskaźnikiem w tej sytuacji byłoby stałe (np. o 5-10\% rocznie) powiększanie społecznych zasobów mieszkaniowych na wynajem ${ }^{56}$ dla gospodarstw domowych o dochodach uniemożliwiających im kupno mieszkania lub wynajem po cenach rynkowych. Bardziej miarodajnym wskaźnikiem byłby zaproponowany w poprzedniej części opracowania wskaźnik zaspokojenia społecznych potrzeb mieszkaniowych, a także wskaźnik dostępności mieszkań o przystępnych czynszach. Z danych Eurostatu wynika, że w 2019 r., czyli przed pandemią i wywołanym nią kryzysem gospodarczym, w Polsce przeciętnie

55 https://www.gov.pl/web/rozwoj-praca-technologia/w-2020-r-wzrosl-odsetek-mieszkan-oddanych-do-uzytku--0-67-proc [dostęp: 30 czerwca 2021 r.].

56 Szerzej na ten temat w: A. Szelągowska, Finansowanie społecznego budownictwa mieszkaniowego, CeDeWu, Warszawa 2011. 
15,9\% ludności mieszkało w wynajmowanym mieszkaniu, podczas gdy średnia UE wynosiła 30,8\% ${ }^{57}$. Z badania przeprowadzonego we wrześniu 2020 r. przez CBRE wynika, że 61\% spośród badanych osób wynajmujących mieszkania przyznało, iż głównym powodem, dla którego zdecydowało się na tę formę zapewnienia sobie lokum, jest brak środków na kupno własnego mieszkania ${ }^{58}$. Ciekawych informacji dostarcza badanie internetowe Własne czy wynajmowane. Preferencje mieszkaniowe młodych ludzi w Polsce, przeprowadzone przez M. Bryxa i I. Rudzką wśród 983 osób między 18. a 45. rokiem życia, zrealizowane w dniach 26 sierpnia-20 września 2020 r. Wynika z niego, że młodzi Polacy wolą mieszkać w mieszkaniach własnościowych, nie w wynajmowanych. Ponad $90 \%$ ankietowanych uważa, że własność mieszkania stabilizuje ich życie, czyni je bezpieczniejszym i poprawia jego jakość ${ }^{59}$. Zaspokojenie potrzeb tej grupy społeczeństwa jest możliwe dzięki realizacji programu Mieszkanie Plus zakładającego budowę na zasadach rynkowych mieszkań na wynajem z opcją dojścia do własności.

Odwiecznym problemem, który decyduje o stopniu realizacji założeń polityki mieszkaniowej, jest wysokość przewidzianych na ten cel środków finansowych. Z danych Eurostatu wynika, że w 2019 r. w Unii Europejskiej w mieszkalnictwo zainwestowano średnio 5,3\% PKB, podczas gdy w Polsce było to zaledwie $2 \%$ (niższy wskaźnik odnotowano tylko w Grecji - 0,7\%). Dla porównania na Cyprze w mieszkalnictwo zainwestowano 7,9\% PKB, w Finlandii - 7,2\%, w Niemczech - 6,6\% i we Francji - 6,4\% ${ }^{60}$. Szczególnie pomocnym rozwiązaniem kwestii mieszkaniowej w Polsce byłoby systematyczne zwiększanie do 2030 r. udziału wydatków na mieszkalnictwo do średniego poziomu UE. Wzrost nakładów na realizację celów polityki mieszkaniowej państwa byłby niezmiernie pomocny w realizacji drugiego celu Narodowego Programu Mieszkaniowego, a więc zapewnieniu samorządom możliwości zaspokojenia potrzeb mieszkaniowych większości (a nie jak zapisano w NPM - wszystkich) osób zagrożonych wykluczeniem społecznym ze względu na niskie dochody lub szczególnie trudną sytuację życiową, oczekujących na wynajem gminnego lokalu. Nigdy nie da się bowiem zaspokoić potrzeb mieszkaniowych wszystkich grup społecznych. Należy jednak dążyć do zwiększania dobrobytu społecznego.

Spośród trzech głównych celów wskazanych w Narodowym Programie Mieszkaniowym najbardziej realne wydaje się obniżenie do 2030 r. liczby osób mieszkających w warunkach substandardowych (a zatem w budynkach będących w złym stanie technicznym, bez podstawowych instalacji technicznych, a także w przeludnieniu) o 2 mln osób. Gdy weźmie się pod uwagę, że przeciętna liczba osób przypadających na jedno mieszkanie wynosiła w Polsce w 2019 r. 2,5961, do końca 2030 r. należałoby oddać w tym celu do użytku 772 tys. mieszkań ${ }^{62}$, czyli średnio po

57 https://ec.europa.eu/eurostat/databrowser/view/ilc_lvho02/default/bar?lang=en [dostęp: 30 czerwca 2021 r.].

58 CBRE, Najem mieszkań w czasie pandemii i postawy wobec zakupu mieszkania - raport z badania rynku, Warszawa 2020, s. 1.

59 M. Bryx, I. Rudzka, Alternatywny model kredytowania hipotecznego na cele mieszkaniowe (raport opracowany na zlecenie Programu Analityczno-Badawczego Fundacji Warszawski Instytut Bankowości), Warszawa 2020, s. 6.

60 Eurostat, Housing in Europe - Statistics visualised. Edition 2020, s. 19.

61 Główny Urząd Statystyczny, Gospodarka mieszkaniowa..., s. 14.

622 mln osób podzielone przez 2,59 osoby przypadającej na jedno mieszkanie. 
85,7 tys. lokali rocznie ${ }^{63}$. W obliczeniach należy uwzględnić również przeciętny czas trwania budowy nowego budynku mieszkalnego, który w 2020 r. wyniósł 38,8 miesiąca ${ }^{64}$. Pomocne mogą być narzędzia realizacji Narodowego Programu Mieszkaniowego obejmujące:

- usprawnienie procesu inwestycyjno-budowlanego - w tym program Lokal za Grunt,

- racjonalizację funkcjonowania zasad rynku najmu,

- rozwój spółdzielczości mieszkaniowej,

- dostępne mieszkania na wynajem,

- społeczne budownictwo czynszowe,

- oszczędzanie na cele mieszkaniowe, które zastąpiono programem dopłat do czynszu Mieszkanie na Start,

- pomoc w ponoszeniu wydatków mieszkaniowych,

- poprawę warunków zamieszkiwania,

- mieszkanie dla seniora.

Zwiększenie dostępu do mieszkań na wynajem dla osób o dochodach uniemożliwiających nabycie lub wynajęcie lokalu na zasadach rynkowych ma nastąpić dzięki programowi Mieszkanie Plus ${ }^{65}$. Obejmuje on program budowy na zasadach rynkowych mieszkań na wynajem z opcją dojścia do własności, adresowanych do osób o umiarkowanych dochodach, posiadających tzw. zdolność czynszową (możliwości terminowego opłacenia czynszu za mieszkanie o danym metrażu). Program ten, stanowiący tzw. rynkową część pakietu Mieszkanie Plus, jest koordynowany przez PFR Nieruchomości SA. W ostatnich latach jest to, zdaniem autorki, jedno z lepszych rozwiązań polskiej polityki mieszkaniowej, choć jego efekty rzeczowe były niewielkie w odniesieniu do zapotrzebowania na takie lokale mieszkalne. PFR Nieruchomości SA zarządza aktywami dwóch zamkniętych funduszy inwestycyjnych - Funduszu Mieszkań na Wynajem ${ }^{66}$ oraz Funduszu Sektora Mieszkań dla Rozwoju ${ }^{67}$. Na koniec lutego 2021 r. w ramach programu wdrażanego przez PFR Nieruchomości SA od 2016 r. wybudowano 1017 mieszkań, a kolejne 2451 lokali było w budowie.

Drugą część, tzw. społeczną, pakietu Mieszkanie Plus stanowi zintegrowany projekt wsparcia społecznego budownictwa czynszowego, na który składają się:

- program wsparcia inwestorów społecznego budownictwa czynszowego budujących mieszkania na wynajem lub mieszkania spółdzielcze lokatorskie, adresowany do osób o średnich dochodach;

- program wsparcia gmin współpracujących z innymi podmiotami przy tworzeniu mieszkań na wynajem o umiarkowanym czynszu, skierowanych do osób o niższych dochodach;

63772 tys. mieszkań podzielone przez 9 lat.

64 https://www.gov.pl/web/rozwoj-praca-technologia/w-2020-r-wzrosl-odsetek-mieszkan-oddanych-do-uzytku--0-67-proc [dostęp: 30 czerwca 2021 r.].

65 Szerzej na ten temat: https://mplus.pl/o-programie/dla-kogo/ oraz https://mieszkanieplus.gov.pl/ [dostęp: 30 czerwca 2021 r.].

66 Szerzej na ten temat: https://funduszmieszkan.pl/ [dostęp: 30 czerwca 2021 r.].

67 Szerzej na ten temat: https://www.pfrtfi.pl/fundusze-inwestycyjne/fundusze-inwestycyjne-zamkniete/ fundusz-FSMDR?code=FSMDR [dostęp: 30 czerwca 2021 r.]. 
- program wsparcia samorządów lokalnych i organizacji pożytku publicznego w zakresie budownictwa komunalnego i wspomaganego, adresowanego do osób o najniższych dochodach oraz osób w najtrudniejszej sytuacji życiowej.

W ramach społecznej części pakietu Mieszkanie Plus dzięki programowi wsparcia budownictwa socjalnego i komunalnego od stycznia 2016 do lutego 2021 r. oddano do użytku 6930 mieszkań, a w budowie było kolejnych 6269 lokali. W analizowanym okresie powstały również 204 miejsca w noclegowniach, schroniskach dla bezdomnych, ogrzewalniach i pomieszczeniach tymczasowych, a kolejne 433 były w budowie. Statystyki te nie są imponujące. W programie społecznego budownictwa czynszowego od stycznia 2016 do końca lutego 2021 r. wybudowano 4184 mieszkania, a kolejnych 5895 lokali było w budowie. Łącznie w ramach pakietu Mieszkanie Plus od stycznia 2016 do końca lutego 2021 r. wybudowano 12131 mieszkań, a w budowie było kolejnych 14695 mieszkań, co daje w okresie de facto pięciu lat 26826 lokali mieszkalnych (program Mieszkanie Plus zakładał wybudowanie do końca 2019 r. 100 tys. mieszkań) ${ }^{68}$.

Program Mieszkanie Plus ma zostać wygaszony i zastąpiony programem Polski Ład. Wśród 10 głównych zagadnień, na których skupia się nowy program, znalazł się także punkt „Rodzina i dom w centrum życia"69. W jego ramach proponuje się pomoc w zakupie mieszkania bez wkładu własnego oraz budowę budynków jednorodzinnych o powierzchni do $70 \mathrm{~m}^{2}$ bez konieczności uzyskania pozwolenia na budowę. Wsparcie jest kierowane do trzech grup klientów (osób od 20. do 40. roku życia i rodzin wielodzietnych): do tych, którzy chcą mieć swoje pierwsze mieszkanie z rynku pierwotnego, tych, którzy szukają go na rynku wtórnym, społecznym, a także do tych, którzy zamierzają wybudować dom. Program Mieszkanie bez Wkładu Własnego zakłada udzielenie gwarancji rządowych w wysokości maksymalnie 100 tys. zł wkładu własnego osobom biorącym kredyt lub dofinansowania w wysokości do 160 tys. zł w przypadku osób korzystających z mieszkalnictwa społecznego czy rodzin wielodzietnych (w zależności od liczby dzieci w gospodarstwie domowym ${ }^{70}$ ). Rocznie z programu ma korzystać do 80 tys. rodzin, a o zakwalifikowaniu się do niego będzie decydować maksymalna cena $1 \mathrm{~m}^{2}$ nabywanej nieruchomości.

W dniu 1 kwietnia 2021 r. weszła w życie ustawa z dnia 16 grudnia 2020 r. o rozliczaniu ceny lokali lub budynków w cenie nieruchomości zbywanych z gminnego zasobu nieruchomości (Dz.U. 2021, poz. 223), zwana programem Lokal za Grunt, a 5 stycznia 2021 r. została wdrożona jego społeczna część. W nowym programie mieszkaniowym kluczową rolę ma odgrywać Krajowy Zasób Nieruchomości (KZN) ${ }^{71}$, będący tzw. bankiem gruntów. Krajowy Zasób Nieruchomości jest państwową osobą prawną utworzoną na mocy ustawy z dnia 20 lipca 2017 r. o Krajowym Zasobie Nieruchomości72. Nadrzędną jego misją jest prowadzenie polityki sprzyjającej zaspoko-

68 https://www.gov.pl/web/rozwoj-praca-technologia/narodowy-program-mieszkaniowy [dostęp: 30 czerwca $2021 \mathrm{r}$.].

69 http://polskilad.pis.org.pl/ [dostęp: 30 czerwca 2021 r.].

70 Wysokość otrzymanego dofinansowania będzie uzależniona od liczby dzieci w rodzinie - 20 tys. zł w przypadku drugiego dziecka, 60 tys. zł - trzeciego, 20 tys. zł - każdego kolejnego.

71 Szerzej na ten temat: https://www.kzn.gov.pl/ [dostęp: 30 czerwca 2021 r.].

72 Dz.U. 2020, poz. 1100, ze zm. 
jeniu potrzeb mieszkaniowych. Do najważniejszych zadań tej instytucji należą: gospodarowanie nieruchomościami wchodzącymi w skład KZN, tworzenie warunków do zwiększenia dostępności mieszkań, podejmowanie działań mających na celu realizację inwestycji mieszkaniowych, tworzenie warunków ułatwiających powstawanie mieszkań gminnych i innych. Krajowy Zasób Nieruchomości współuczestniczy w realizacji rządowego programu Mieszkanie Plus. Na koniec grudnia 2020 r. KZN posiadał blisko 900 ha gruntów w 122 lokalizacjach w całej Polsce. Według szacunków tej instytucji na tym obszarze może powstać ok. 67 tys. mieszkań. Krajowy Zasób Nieruchomości ma również tworzyć społeczne inicjatywy mieszkaniowe (SIM), będące odpowiednikami towarzystw budownictwa społecznego, a także przystępować do nowo tworzonych SIM. Nowy model zaspokajania potrzeb mieszkaniowych polega bowiem na powołaniu przez jednostkę samorządu terytorialnego społecznej inicjatywy mieszkaniowej z KZN reprezentującym Skarb Państwa. Krajowy Zasób Nieruchomości dysponujący gruntem państwowym wnosi go do społecznej inicjatywy mieszkaniowej w celu umożliwienia na nim budowy lokali mieszkalnych. Każda z gmin przystępujących do społecznej inicjatywy mieszkaniowej może wystąpić z wnioskiem do KZN o jednorazowe wsparcie z Rządowego Funduszu Rozwoju Mieszkalnictwa (RFRM) w wysokości do 3 mln zł. Kolejnym krokiem, który ma ułatwić finansowanie inwestycji, będzie bezzwrotne dofinansowanie z RFRM w wysokości do 10\% kosztów realizacji inwestycji ${ }^{73}$.

W dniu 1 lutego 2021 r. zawarto pierwsze porozumienie w sprawie utworzenia społecznej inicjatywy mieszkaniowej przez Krajowy Zasób Nieruchomości i miasto Stalową Wolę. W ramach umowy KZN wniósł do spółki 3-hektarową działkę na osiedlu Charzewice przy ul. Ogrodowej, na której ma powstać 240 mieszkań na wynajem dla osób i rodzin, które nie mogą sobie pozwolić na zakup mieszkania lub budowę domu za pieniądze z kredytu. Docelowo na tym osiedlu ma powstać do 1250 mieszkań74. Kolejne porozumienie podpisano 6 lutego 2021 r. z sześcioma gminami województwa łódzkiego (Radomsko, Sieradz, Skierniewice, Pabianice, Piotrków Trybunalski, Bełchatów), gdzie na obszarze 6 ha ma zostać wybudowane łącznie ok. 500 mieszkań ${ }^{75}$. Zgodnie z zapowiedziami z 22 marca 2021 r. KZN dąży do powołania spółek SIM w różnych regionach Polski, gdzie na 570 ha może powstać ok. 18 tys. mieszkań ${ }^{76}$. Jest to znacznie mniej, niż planowano w ramach programu Mieszkanie Plus, ale cenna jest każda inicjatywa zwiększająca stan zasobów mieszkaniowych dla niezamożnych gospodarstw domowych, posiadających zdolność czynszową, nieposiadających zdolności kredytowej.

Tak zwaną covidową politykę mieszkaniową tworzy pakiet mieszkaniowy oparty na przepisach ustawy z dnia 10 grudnia 2020 r. o zmianie niektórych ustaw wspierających rozwój mieszkalnictwa ${ }^{77}$. Efektami społecznej części pakietu mają być:

- wyższe wsparcie finansowe budownictwa społecznego i komunalnego oraz łatwiejszy dostęp do gruntów pod zabudowę, realizowane m.in. przez wspomnianą wcześniej ustawę o rozliczaniu ceny lokali lub budynków w cenie nieruchomości zbywanych z gminnego zasobu

\footnotetext{
73 https://www.kzn.gov.pl/2021/03/22/bedziemy-budowac-na-podkarpaciu/ [dostęp: 30 czerwca 2021 r.].

74 https://www.kzn.gov.pl/2021/02/03/nowy-lad-mieszkaniowy/ [dostęp: 30 czerwca 2021 r.].

75 https://www.kzn.gov.pl/2021/02/12/inwestycja-na-szostke/ [dostęp: 30 czerwca 2021 r.].

76 https://www.kzn.gov.pl/2021/03/22/bedziemy-budowac-na-podkarpaciu/ [dostęp: 30 czerwca 2021 r.].

77 Dz.U. 2021, poz. 11.
} 
nieruchomości. Gminy mogą liczyć na pokrycie maks. 80\% kosztów budowy nowych mieszkań komunalnych oraz na zwiększenie grantów z Funduszu Dopłat Banku Gospodarstwa Krajowego na budowę mieszkań społecznych - z 20\% do 35\% kosztów inwestycji. Wprowadzono także zasadę finansowania wkładu gminy, a nie refinansowania;

- zwiększenie dostępności mieszkań na wynajem dla osób o niskich dochodach - w marcu 2021 r. Rada Ministrów przyjęła projekt nowelizacji wspomnianej ustawy o niektórych formach popierania budownictwa mieszkaniowego oraz niektórych innych ustaw. Projekt zakłada m.in. wprowadzenie do systemu prawa modelu społecznych agencji najmu (SAN). Dzięki pośrednictwu spółek gminnych i organizacji społecznych gmina będzie mogła zapewnić mieszkania na wynajem tym członkom wspólnoty samorządowej, którzy mają trudności z samodzielnym uzyskaniem mieszkania na rynku. Nawiązanie przez gminę współpracy z SAN ma umożliwić wykorzystanie istniejących już lokali, pozyskanych np. z komercyjnego rynku najmu. Ponadto dzięki gwarancji terminowego uiszczania opłat czynszowych, stabilnego użytkowania i utrzymania mieszkań w dobrym stanie technicznym oraz dzięki zwolnieniom podatkowym dla właścicieli z tytułu umowy z SAN społeczne agencje najmu będą mogły wydzierżawiać mieszkania poniżej stawek rynkowych. Pozwoli im to na wynajmowanie tych mieszkań osobom, które znajdują się w trudnej sytuacji życiowej i nie mogą sobie pozwolić na samodzielny wynajem lub zakup mieszkania. Dodatkowo najemcy mieszkań od SAN będą mogli ubiegać się o dopłaty do czynszu w ramach programu Mieszkanie na Start;

- poprawa warunków mieszkaniowych w już istniejących lokalach, realizowana przez wyższe granty na remonty zasobu budynków komunalnych, które ze względu na stan techniczny nie są użytkowane (pustostany), oraz przez uproszczoną procedurę ubiegania się o premie remontowe w przypadku budynków TBS starszych niż 20 lat (dotychczas ogólna zasada pozwalała uzyskać ze środków Funduszu Termomodernizacji i Remontów premię na remont budynku wybudowanego przed 1961 r.);

- dopłaty do czynszu dla podnajemców mieszkań - w dniu 5 stycznia 2021 r. weszły w życie przepisy umożliwiające przyznanie przez gminy lokali mieszkalnych najemcom oraz podnajemcom, którzy zostali dotknięci ekonomicznymi skutkami epidemii COVID-19, a także dodatków mieszkaniowych powiększonych o tzw. dopłatę do czynszu. Dopłata do czynszu jest finansowana ze środków Funduszu Przeciwdziałania COVID-19, należy jednak podkreślić, że dodatek mieszkaniowy powiększony o dopłatę do czynszu przysługuje wyłącznie najemcy lub podnajemcy lokalu mieszkalnego, czyli nie mogą z niego skorzystać osoby zamieszkujące własne mieszkanie;

- wakacje czynszowe dla najemców lokali społecznych inicjatyw mieszkaniowych (SIM) - obecnych towarzystw budownictwa społecznego - którzy nie zdecydują się na wykup mieszkania na własność. Udział najemców w kosztach budowy lokalu z TBS może zostać rozliczony na trzy sposoby: w celu dojścia do własności mieszkania lub w celu skorzystania ze wspomnianych wakacji czynszowych, a więc uzyskania długookresowej i ciągłej obniżki czynszu albo obniżki okresowej (nawet 20-procentowej). Każdy z wariantów będzie możliwy dopiero po spłacie przez spółkę kredytu preferencyjnego z Banku Gospodarstwa Krajowego (BGK). Warunkiem 
skorzystania przez wnioskodawcę z wakacji czynszowych jest bycie stroną umowy najmu z partycypacją od co najmniej pięciu lat. Wykluczone z możliwości rozliczenia partycypacji są osoby, które w ostatnich pięciu latach zalegały z czynszem lub opłatami za mieszkanie przez okres dłuższy niż trzy miesiące. Dodatkowo SIM lub TBS będą mogły odrzucić wniosek o rozliczenie partycypacji, jeśli w okresie co najmniej pięciu lat przed spłatą preferencyjnego kredytu na budowę mieszkań roczny czynsz pobierany od wnioskodawcy nie przekraczał odpowiednio 3,5\% lub 4,5\% wartości odtworzeniowej zajmowanego lokalu. Niższy limit (3,5\%) ma dotyczyć mieszkań zbudowanych z wykorzystaniem kredytu z BGK, o który wnioskowano do 30 września 2009 r., a wyższy limit - lokali powstałych z zastosowaniem tzw. finansowania zwrotnego;

- możliwość dojścia do własności w nowo budowanych mieszkaniach w SIM - poza wprowadzeniem do oferty mieszkań na wynajem z atrakcyjną stawką czynszową pakiet mieszkaniowy zakłada również możliwość dojścia do własności wynajmowanego lokalu. Będzie wówczas wymagany od lokatora wkład partycypacyjny na pokrycie co najmniej 20\% (lub $25 \%$ w dużych miastach) kosztów budowy. Z wnioskiem o zamianę dotychczasowej umowy najmu na umowę najmu z dojściem do własności będzie można wystąpić po spłaceniu przez SIM/TBS kredytu zaciągniętego na inwestycję;

- powstanie Rządowego Funduszu Rozwoju Mieszkalnictwa, który został utworzony w Banku Gospodarstwa Krajowego na mocy ustawy z dnia 10 grudnia 2020 r. o zmianie niektórych ustaw wspierających rozwój mieszkalnictwa. Jego celem jest poprawa dostępności mieszkań przez pobudzenie nowych inwestycji mieszkaniowych na rynku mieszkań budowanych z przeznaczeniem na wynajem przez społeczne inicjatywy mieszkaniowe (SIM). Do wykorzystania w ramach funduszu są środki w wysokości 1,5 mld zł mające być wsparciem dla gmin w budowie mieszkań;

- nowe tytuły wydatkowe, w związku z którymi właściciele książeczek mieszkaniowych będą mogli otrzymać premię gwarancyjną - nowe regulacje prawne zaczęły obowiązywać od 19 stycznia 2021 r. na mocy ustawy z dnia 10 grudnia 2020 r. o zmianie niektórych ustaw wspierających rozwój mieszkalnictwa. Właściciele książeczek mieszkaniowych założonych do dnia 23 października 1990 r. mają możliwość uzyskania premii w związku z wniesieniem opłaty z tytułu przekształcenia prawa użytkowania wieczystego w prawo własności. Mogą oni również realizować nowe przedsięwzięcia remontowe, m.in. wymianę okien, instalacji wodno-kanalizacyjnej, instalacji elektrycznej, c.o., wymianę źródeł ciepła. Rozwiązanie to umożliwia także posiadaczom książeczek mieszkaniowych uwzględnienie wydatków związanych z zawarciem umowy najmu instytucjonalnego z dojściem do własności. Premia ma być wówczas przekazywana przed uzyskaniem własności mieszkania tytułem spłaty części kapitałowej. W ramach nowych tytułów wydatkowych zakłada się również wprowadzenie rozwiązań pozwalających w większym stopniu powiązać sytuację osoby nadal będącej posiadaczem książeczki mieszkaniowej z możliwością taniego wynajmu nowego mieszkania (z opcją dojścia do własności takiego mieszkania) przez danie właścicielom książeczek mieszkaniowych pierwszeństwa przy naborze wniosków o zawarcie umowy najmu w programie Mieszkanie na Start. Do końca 2022 r. trzeba będzie zarejestrować posiadaną książeczkę mieszkaniową 
w banku prowadzącym obsługę rachunku, dzięki czemu będzie możliwa zarówno weryfikacja liczby rzeczywiście istniejących książeczek mieszkaniowych, jak i oszacowanie kwoty łącznych zobowiązań budżetowych wobec ich posiadaczy ${ }^{78}$;

- pomoc dla najemców dotkniętych ekonomicznymi skutkami COVID-19, obejmująca m.in. dopłaty do czynszu w programie Mieszkanie na Start także dla osób bez zdolności czynszowej (opcja dla „stających na nogi” obejmuje dopłaty do czynszu również dla lokatorów mieszkań wynajmowanych od inwestora przez gminę i podnajmowanych lokatorowi). Dopłaty do czynszu finansowane ze środków Funduszu Przeciwdziałania COVID-19 przysługują najemcom lub podnajemcom lokalu mieszkalnego, otrzymującym dodatek mieszkaniowy, których dochód w stosunku do 2019 r. uległ obniżeniu co najmniej o 25\% w stosunku do średniego miesięcznego dochodu przypadającego na jednego członka gospodarstwa domowego w okresie trzech miesięcy poprzedzających datę złożenia wniosku o przyznanie dodatku mieszkaniowego. Dodatek mieszkaniowy powiększony o dopłatę do czynszu stanowi 75\% miesięcznego czynszu opłacanego przez najemcę, jednak nie może przekroczyć kwoty 1500 zł przez okres sześciu miesięcy. Dodatek nie jest przyznawany osobom zamieszkującym własne mieszkanie;

- cyfryzacja procesu budowlanego polegająca na stopniowym przechodzeniu z papierowej formy wypełniania zawiadomień i wniosków w procesie budowlanym na formę elektroniczną. Cyfryzacja procesu budowlanego jest efektem zmian wprowadzonych jesienią $2020 \mathrm{r}$. w ustawie z dnia 27 marca 2003 r. o planowaniu i zagospodarowaniu przestrzennym ${ }^{79}$. Od lutego 2021 r. przez oficjalną rządową aplikację do składania wniosków w procesie budowlanym można złożyć 13 wniosków związanych z takim procesem ${ }^{80}$. Dzięki cyfryzacji aktów planowania przestrzennego będzie możliwe uzyskanie pełnej i jednolitej informacji o ustaleniach planistycznych w skali całego państwa. W 2021 r. mają być także wprowadzone: centralny rejestr osób posiadających uprawnienia budowlane w wersji elektronicznej (e-CRUB), Elektroniczny Dziennik Budowy oraz dalsze usprawnienia w procesie inwestycyjno-budowlanym. Od 1 lipca 2021 r. można składać elektroniczne wnioski m.in. o pozwolenie na budowę wraz z załączonym projektem zagospodarowania działki lub terenu oraz projektem architektoniczno-budowlanym, o zmianę pozwolenia na budowę, o wydanie pozwolenia na budowę tymczasowego obiektu budowlanego, o odstępstwo od przepisów techniczno-budowlanych, o wszczęcie uproszczonego postępowania legalizacyjnego, o pozwolenie na użytkowanie, a także zawiadomić o zakończeniu budowy. Z kolei od 5 lipca 2021 r. jest

78 Według stanu na 31 grudnia 2018 r. były zarejestrowane 1032033 rachunki oszczędnościowe, do których wydano książeczki mieszkaniowe. Zgromadzone na tych rachunkach wkłady na koniec 2018 r. miały wartość 532,8 mln zł, ze średnią premią gwarancyjną wynoszącą w 2018 r. 9315,4 zł. Według danych PKO BP SA (posiadającego ponad 99\% portfela rachunków książeczek mieszkaniowych uprawniających do premii gwarancyjnej) na dzień 30 września 2020 r. liczba książeczek mieszkaniowych wynosiła 1007 684; https://www. podatki.biz/artykuly/co-dalej-z-ksiazeczkami-mieszkaniowymi_52_45917.htm [dostęp: 30 czerwca 2021 r.] oraz https://www.rpo.gov.pl/pl/raport_1/933 [dostęp: 30 czerwca 2021 r.].

79 Dz.U. 2021, poz. 741, ze zm.

80 https://e-budownictwo.gunb.gov.pl/ [dostęp: 30 czerwca 2021 r.]. 
możliwe elektroniczne zgłoszenie budowy lub robót budowlanych z projektem zagospodarowania działki lub terenu i z projektem architektoniczno-budowlanym ${ }^{81}$.

Przedstawione powyżej działania przewidziane w społecznej części pakietu mieszkaniowego są ambitne, choć w niewielkim stopniu ułatwiają osiągnięcie głównego celu Narodowego Programu Mieszkaniowego, jakim jest zrównanie do 2030 r. liczby mieszkań na 1000 mieszkańców ze średnią unijną. Wynika to z wadliwie skalkulowanego mianownika, nieuwzględniającego zmian demograficznych w perspektywie długoterminowej. 0 wiele większe są szanse realizacji dwóch pozostałych celów Narodowego Programu Mieszkaniowego, czyli uzyskania przez samorządy możliwości zaspokojenia potrzeb mieszkaniowych osób zagrożonych wykluczeniem społecznym ze względu na niskie dochody lub szczególnie trudną sytuację życiową, oczekujących na najem gminnego lokalu oraz obniżenie liczby osób mieszkających w warunkach substandardowych. Trzeba jednak przyznać, że zaproponowane rozwiązania to krok w dobrą stronę, choć powinny być wdrożone co najmniej w połowie poprzedniej dekady.

Zdaniem autorki stosunkowo mało miejsca w Narodowym Programie Mieszkaniowym poświęcono zrównoważonemu budownictwu mieszkaniowemu. Polska gospodarka, podobnie jak gospodarka każdego państwa członkowskiego Unii Europejskiej, musi stać się zeroemisyjna do 2050 r. Przy realizacji społecznych programów mieszkaniowych powinno się zatem stosować proekologiczne rozwiązania w procesie inwestycyjnym lub wymagać tego od wykonawców. Nowe inwestycje mieszkaniowe, jak również remontowane zasoby mieszkaniowe muszą być zeroemisyjne i energooszczędne, aby sprostać wyzwaniom zrównoważonego rozwoju. Społeczne budownictwo mieszkaniowe powinno spełniać oczekiwania dotyczące niskiego zużycia wody i energii, ekologicznego doboru materiałów, odpowiedniego układu funkcjonalnego dostosowanego m.in. do potrzeb seniorów lub osób wymagających opieki, dostępu do zieleni zapewnionego wszystkim mieszkańcom, a także przystępnego czynszu. Idealnym rozwiązaniem byłoby stosowanie w nowych inwestycjach budownictwa społecznego m.in. zintegrowanej fotowoltaiki, wind z technologią odzysku energii, systemów odzysku wody deszczowej do nawadniania terenów zielonych czy oświetlenia LED sterowanego czujnikami ruchu, dzięki którym maleje zużycie energii wykorzystywanej w częściach wspólnych nieruchomości. Ekoinnowacje powinny nieustannie towarzyszyć wszystkim obywatelom bez względu na ich status społeczny i finansowy. Budownictwo zużywa ponad 50\% światowej energii ${ }^{82}$, a przez to znacząco oddziałuje na emisję $\mathrm{CO}_{2}$, dlatego tak ważne jest podejmowanie decyzji na etapie projektowym. Co prawda na początku 2021 r. Ministerstwo Rozwoju, Pracy i Technologii zapowiedziało przeprowadzenie do 2050 r. głębokiej termomodernizacji, która ma objąć budynki użyteczności publicznej, usługowe, administracji, a także budynki wielorodzinne i jednorodzinne, tak by stały się zeroemisyjne. Trudno jednak doszukać się w komunikatach rządowych działań w tym zakresie w odniesieniu do komunalnych zasobów mieszkaniowych oraz istniejących zasobów budownictwa społecznego. Na tym etapie powinny być już przygotowane plany przekwaterowania lokatorów z zasobów mieszkaniowych gmin, które

81 Szerzej na ten temat: https://www.gov.pl/web/rozwoj-praca-technologia/od-papierowej-do-cyfrowej-dokumentacji--unowoczesniamy-proces-inwestycyjno-budowlany [dostęp: 30 czerwca 2021 r.].

82 https://ec.europa.eu/energy/eu-buildings-factsheets-topics-tree/energy-use-buildings_en 
mają być remontowane i gruntownie termomodernizowane, do innych, nowo wyremontowanych mieszkań lub nowych lokali. Harmonogram oddawania nowych mieszkań i remontowania starych powinien być spójny i odpowiednio zaplanowany, aby modernizacje nie były uciążliwe dla mieszkańców. Kolejnym ważnym aspektem polityki mieszkaniowej jest stworzenie ogólnopolskiej cyfrowej bazy informacji o sytuacji mieszkaniowej Polaków, pomocnej w ocenie społecznych potrzeb mieszkaniowych. Scentralizowana lista gospodarstw domowych oczekujących na przydział lokalu pokazywałaby skalę potrzeb i mogłaby łączyć inwestorów zainteresowanych budową mieszkań z gminami. Innym rozwiązaniem, które mogłoby się przyczynić do pozyskania środków z rynku na realizację inwestycji przez gminy, są obligacje skarbowe lub bony mieszkaniowe nabywane przez osoby fizyczne szukające atrakcyjniejszych ofert lokowania wolnych środków finansowych. Wyzwań związanych ze współczesną polityką mieszkaniową jest o wiele więcej, co oznacza, że kwestie mieszkalnictwa wymagają jeszcze większej uwagi decydentów i holistycznego podejścia.

\section{Podsumowanie}

Polityka mieszkaniowa stanowi poważne wyzwanie zarówno w teorii, jak i w praktyce. Potrzeby mieszkaniowe rosną, podobnie jak oczekiwania obywateli. Pandemia COVID-19 pokazała, jak nieprzewidywalne skutki dla gospodarki i dla gospodarstw domowych może mieć rozprzestrzenianie się jednego wirusa. Lockdown jeszcze bardziej unaocznił potrzeby mieszkaniowe tych gospodarstw domowych, które mieszkają w warunkach przeludnienia. Większość obywateli zaczęła dostrzegać sensowność zaleceń urzędów statystycznych dotyczących liczby mieszkańców przypadających na jedną izbę oraz minimalnej powierzchni przypadającej na jednego mieszkańca. Należy jednak podkreślić, że polska polityka mieszkaniowa w ostatnich latach wzbogaciła się o wiele instrumentów zwiększających skuteczność działań na rzecz zaspokajania potrzeb mieszkaniowych niezamożnych gospodarstw domowych. Inicjatywy rządu w obszarze mieszkalnictwa, które zaplanowano na 2021 r. i następne lata, mimo zwiększenia nakładów na politykę mieszkaniową nadal tylko częściowo odpowiadają na wyzwania współczesnej polityki mieszkaniowej. Tym samym, pomimo szerokiego instrumentarium polityki mieszkaniowej, realizacja głównego celu NPM do 2030 r. nie jest możliwa. Polityka mieszkaniowa zawsze będzie odgrywać kluczową rolę w polityce gospodarczej i społecznej państwa. Od zaspokojenia podstawowych potrzeb obywateli zależą ich dobrobyt i chęć uczestnictwa w życiu społeczno-gospodarczym. Co więcej, żyjemy w erze starzejącego się społeczeństwa i już dziś należy zawrzeć w długoterminowej polityce mieszkaniowej działania na rzecz zaspokajania potrzeb seniorów (jedną z nich są np. szczególne warunki mieszkaniowe) oraz osób niepełnosprawnych, które z niskich emerytur nie pokryją podstawowych kosztów życia. Państwo w ramach polityki mieszkaniowej powinno holistycznie podchodzić do rozwoju mieszkalnictwa we wszystkich jego formach i poszukiwać rozwiązań, które stanowiłyby zachętę dla osób wykluczonych mieszkaniowo do podejmowania działań zmierzających do poprawy warunków mieszkaniowych. Każdy rządowy program mieszkaniowy powinien motywować poszczególne grupy społeczne do pracy i umożliwiać im jednocześnie korzystanie ze wsparcia publicznego w sytuacji uniemożliwiającej ponoszenie kosztów utrzymania mieszkania. 


\section{Bibliografia}

Acocella N., Zasady polityki gospodarczej, PWN, Warszawa 2002.

Bryx M., Rudzka I., Alternatywny model kredytowania hipotecznego na cele mieszkaniowe (raport opracowany na zlecenie Programu Analityczno-Badawczego Fundacji Warszawski Instytut Bankowości), Warszawa 2020.

Bryx M., Szelągowska A., Rozwój zasobu mieszkań dostępnych w stolicy w perspektywie 2030 (ekspertyza dla Biura Polityki Lokalowej Urzędu Miasta Warszawy), Warszawa 2018.

Florczak-Wątlor M., Obowiq̨zek ochrony beneficjentów prawa do mieszkania jako "innego prawa majatkowego" w rozumieniu art. 64 ust. 1 i 2 Konstytucji RP, „Gdańskie Studia Prawnicze” 2018, t. 40.

Garlicki L., Komentarz do art. 75 [w:] Konstytucja RP. Komentarz, t. III, red. L. Garlicki, Wydawnictwo Sejmowe, Warszawa 2003.

International Perspectives on Homeless, red. V. Polakow, C. Guillean, Greenwood Press, Westport 2001.

Jarosz-Żukowska S., Przedmiot i specyfika ochrony własności w przepisach konstytucyjnych - ujęcie polskie na tle porównawczym [w:] „Prace Naukowe Wydziału Prawa, Administracji i Ekonomii Uniwersytetu Wrocławskiego” 2017, nr 92 [Własność w prawie i gospodarce, red. U. Kalina-Prasznic].

Kaltenberg-Kwiatkowska E., Społeczne problemy mieszkalnictwa i socjologia mieszkania [w:] Mieszkanie. Analiza socjologiczna, red. E. Kaltenberg-Kwiatkowska, Polskie Wydawnictwo Ekonomiczne, Warszawa 1982.

Kurzynowski A., Zwiqzzki polityki społecznej z polityka gospodarcza [w:] Polityka społeczna, red. A. Kurzynowski, Oficyna Wydawnicza SGH, Warszawa 2001.

Lis P., Polityka państwa w zakresie finansowania inwestycji mieszkaniowych, C.H. Beck, Warszawa 2008.

Mączyński A., Prawo do mieszkania w świetle Konstytucji RP [w:] Godność człowieka a prawa ekonomiczne i socjalne. Księga jubileuszowa wydana w piętnastą rocznicę ustanowienia Rzecznika Praw Obywatelskich, Biuro Rzecznika Praw Obywatelskich, Warszawa 2003.

Mieszkalnictwo. Zagrożenia i szanse rozwoju, red. H. Kulesza, W. Nieciuński, Polskie Wydawnictwo Ekonomiczne, Warszawa 1989.

Raport o stanie polskich miast. Mieszkalnictwo społeczne, red. A. Muzioł-Węcławowicz, K. Nowak, Instytut Rozwoju Miast i Regionów, Warszawa 2018.

Szarfenberg R., Krytyka i afirmacja polityki społecznej, Instytut Filozofii i Socjologii PAN, Warszawa 2008.

Szelągowska A., Finansowanie społecznego budownictwa mieszkaniowego, CeDeWu, Warszawa 2011.

Szelągowska A., Koncepcja programu Mieszkanie dla Młodych a kwestia mieszkaniowa w Polsce, „Prace Naukowe Wyższej Szkoły Bankowej w Gdańsku" 2013, t. 27, s. 251-259.

Szelągowska A., Program „Rodzina na swoim” jako instrument polityki mieszkaniowej rzqdu stymulujacy popyt na kredyty mieszkaniowe [w:] Współczesna bankowość hipoteczna, red. A. Szelągowska, CeDeWu, Warszawa 2010.

Szelągowska A., Społeczne potrzeby mieszkaniowe a światowa teoria potrzeb [w:] Współczesne wyzwania dla lokalnej polityki społecznej, red. M. Gagacka, K. Głąbicka, Wydawnictwo Politechniki Radomskiej, Radom 2007. Tinbergen J., Economic Policy. Principles and Design, Elsevier-North Holland, Amsterdam 1956.

\section{Dokumenty, raporty}

CBRE, Najem mieszkań w czasie pandemii i postawy wobec zakupu mieszkania - raport z badania rynku, Warszawa 2020. 
Eurostat, Housing in Europe - Statistics visualised. Edition 2020.

Główny Urząd Statystyczny, Budownictwo mieszkaniowe w okresie I-XII 2020 r. Informacja sygnalna, Warszawa 2021.

Główny Urząd Statystyczny, Gospodarka mieszkaniowa i infrastruktura komunalna w 2019 r., Warszawa 2020.

Główny Urząd Statystyczny, Ludność. Stan i struktura ludności oraz ruch naturalny w przekroju terytorialnym w 2020 r.

Stan w dniu 30 czerwca 2020, Warszawa 2021.

Ministerstwo Rozwoju, Raport. Stan mieszkalnictwa w Polsce, Warszawa 2020.

Najwyższa Izba Kontroli, Informacja o wynikach kontroli. Działania administracji publicznej na rzecz zaspokajania potrzeb mieszkaniowych gospodarstw domowych o niskich dochodach. 16/2020/P/19/033/KIN, Warszawa 2020, https://www.nik.gov.pl/aktualnosci/lokale-socjalne-i-komunalne.html.

Strategia długofalowego rozwoju sektora mieszkaniowego na lata 2005-2025 (projekt dokumentu), Warszawa 2005.

\section{Akty prawne}

Konstytucja Rzeczypospolitej Polskiej z dnia 2 kwietnia 1997 r. (Dz.U. nr 78, poz. 483, ze zm.).

Rezolucja Parlamentu Europejskiego z dnia 10 maja 2007 r. w sprawie mieszkalnictwa i polityki regionalnej 2006/2108(INI) (Dz. Urz. UE C 76E z 27 marca 2008 r.).

Uchwała nr 115/2016 Rady Ministrów z dnia 27 września 2016 r. w sprawie przyjęcia Narodowego Programu Mieszkaniowego (RM-111-119-16), https://narodowyprogram.pl/wp-content/uploads/2017/03/uchwa\%C5\%82a_ narodowy_program_mieszkaniowy.pdf.

Uchwała Sejmu Rzeczypospolitej Polskiej z dnia 6 lipca 1995 r. w sprawie polityki mieszkaniowej Państwa w okresie transformacji społeczno-gospodarczej (M.P. 1995, nr 35, poz. 412).

Ustawa z dnia 8 marca 1990 r. o samorządzie gminnym (Dz.U. 2020, poz. 713, ze zm.).

Ustawa z dnia 21 czerwca 2001 r. o ochronie praw lokatorów, mieszkaniowym zasobie gminy i o zmianie Kodeksu cywilnego (Dz.U. 2020, poz. 611, ze zm.).

Ustawa z dnia 27 marca 2003 r. o planowaniu i zagospodarowaniu przestrzennym (Dz.U. 2021, poz. 741, ze zm.). Ustawa z dnia 8 września 2006 r. o finansowym wsparciu rodzin innych osób w nabywaniu własnego mieszkania (Dz.U. 2021, poz. 403).

Ustawa z dnia 20 lipca 2017 r. o Krajowym Zasobie Nieruchomości (Dz.U. 2020, poz. 1100, ze zm.).

Ustawa z dnia 10 grudnia 2020 r. o zmianie niektórych ustaw wspierających rozwój mieszkalnictwa (Dz.U. 2021, poz. 11).

Ustawa z dnia 16 grudnia 2020 r. o rozliczaniu ceny lokali lub budynków w cenie nieruchomości zbywanych z gminnego zasobu nieruchomości (Dz.U. 2021, poz. 223).

\section{Strony internetowe}

https://appsso.eurostat.ec.europa.eu/nui/show.do?dataset=ilc_mdho01\&lang=en. https://bdl.stat.gov.pl/BDL/dane/podgrup/tablica.

https://ec.europa.eu/eurostat/databrowser/view/ilc_lvho02/default/bar?lang=en.

https://funduszmieszkan.pl/.

https://mieszkanieplus.gov.pl/.

https://mplus.pl/o-programie/dla-kogo/. 
https://sdg.gov.pl/statistics_nat/1-4-a.

https://www.gov.pl/web/rozwoj-praca-technologia/narodowy-program-mieszkaniowy.

https://www.gov.pl/web/rozwoj-praca-technologia/w-2020-r-wzrosl-odsetek-mieszkan-oddanych-do-uzytku--0-67-proc.

https://www.kzn.gov.pl/.

https://www.kzn.gov.pl/2021/02/03/nowy-lad-mieszkaniowy/.

https://www.kzn.gov.pl/2021/02/12/inwestycja-na-szostke/.

https://www.kzn.gov.pl/2021/03/22/bedziemy-budowac-na-podkarpaciu/.

https://www.money.pl/gospodarka/coraz-wiecej-polakow-wymeldowuje-sie-z-kraju-polityka-podatkowa-rzadu-ulatwia-im-decyzje-6573874458864512a.html.

https://www.muratorplus.pl/biznes/prawo/budynek-rekreacji-indywidualnej-jakie-warunki-budowy-domku-letniskowego-aa-iKCk-YBr1-eHTk.html.

https://www.oecd.org/els/family/HM1-1-Housing-stock-and-construction.pdf.

https://www.pfrtfi.pl/fundusze-inwestycyjne/fundusze-inwestycyjne-zamkniete/fundusz-FSMDR?code=FSMDR. https://www.podatki.biz/artykuly/co-dalej-z-ksiazeczkami-mieszkaniowymi_52_45917.htm.

https://www.rpo.gov.pl/pl/raport_1/933.

https://www.sverigesallmannytta.se/. 